\title{
OPTIMUM PARAMETER SELECTION FOR THE MORPHOMETRIC DESCRIPTION OF WATERSHEDS: A CASE STUDY OF CENTRAL NIGERIA
}

\author{
Solomon Olakunle Bilewu' ${ }^{1}$, Bolaji Sule' ${ }^{1}$, Ayanniyi Ayanshola ${ }^{1}$ \\ 1 University of Ilorin, Kwara State, Ilorin, Nigeria, e-mail: bilewuk@yahoo.com; bfsuleiman@gmail.com; \\ engramayanshola@gmail.com
}

Received: 2015.06.30

Accepted: 2015.08.31

Published: 2015.10.01

\begin{abstract}
Hydrological models are very useful for predictions in many ungauged basins across the world. There are many hydrological models available for discharge data generation with different complexities and varied input parameter requirements. Studies have shown that models with many input parameters do not necessarily perform better than those with few input parameters. Basin morphometric parameters play significant roles in the conversion of rainfall to runoff and obtaining good estimates of these parameters for use in runoff models is sometime challenging as Inaccurate input into models can propagate errors and make the models to perform poorly. This study employs the method of principal component analysis to reduce the number of morphometric parameters required to run a runoff model without losing any major information. Parameters for five selected study basins in central Nigeria were measured and analysed. The result shows that three morphometric parameters (Fitness Ratio, Ruggedness Number and Watershed Eccentricity) can adequately represent other parameters as an input into a runoff model for the basins. This reduces significantly the time and effort needed to compute all the parameters which in actual fact may not improve the quality or efficiency of the runoff model.
\end{abstract}

Keywords: morphometry, runoff, eigenvalues, variance, correlation.

\section{INTRODUCTION}

Quantitative assessment of hydrological variables, such as precipitation, evaporation, infiltration and runoff, and their use in water balance studies or in the problems of design and forecasting will only be rational when they are applied to an area with well-defined boundaries or a drainage basin. Runoff from a drainage basin is influenced by various physiographic and climatic factors. Climatic factors are natural occurrences usually outside man's influence. While the physiographic factors may be influenced, they generally vary only with respect to geological time and may thus be constant.

Morphometry is a quantitative description and analysis of the landform of a basin or watershed. The landform has been shown to have a significant effect on water output from a watershed [Howard, 1990; Doad et al., 2012; Ezemonye \&
Emeribe, 2013]. The landform is quantified with some parameters which fully describes the basin physical characteristics. These include the basin size (Area, Perimeter), shape factors, drainage density and intensity, bifurcation ratio and stream density among others [Pal et al., 2012].

In recognition of the usefulness of these parameters in the hydrological prediction of basins, many morphometric studies have been carried out in different parts of the world with varying degree of accuracy [Golekar et al., 2013; Nanda et al., 2014; Al-Saud, 2009] and in Nigeria [Ajibade et al., 2010; Eze \& Effiong, 2010]. In the past, the measurement of these parameters has been done with maps but there has been an improvement in the measurements with the application of GIS and remote sensing [Pareta, 2012; Pingale et al., 2012]. However, these processes can sometimes be expensive in areas with relatively low IT penetration and uncertainty can 
be large. Data interpretation may also be difficult [Zhang et al., 2015].

There are several basin characteristics of hydrological relevance. Many of them are interrelated and it is therefore reasonable to determine which of the parameters has the greatest influence on basin quantitative and hydrological analysis. This will help reduce the number of parameters required for modelling a basin without necessarily increasing model uncertainty. This study applies the method of principal component analysis to extract the most important information from the parameter set and reduce the number of the parameters needed for rainfall - runoff modelling in central Nigeria.

\section{METHOD OF STUDY}

Five drainage basins were selected across central Nigeria and demarcated on a 1:50,000 topographical map. GIS maps of the basins to the same scale were used for quality control. The various physiographic parameters determined for the basins include:

- Catchment (basin) area - this is the most important basin parameter in hydrological analysis. The boundary of the area is determined by ridge separating water flowing in opposite directions. Basins located in plains and coastal areas were not chosen because delineation of catchment area along the ridge line might be difficult in such areas.

- Catchment (basin) shape - the shape of the basin influences the time taken for water from the remote part of the catchment to arrive at the outlet. The shape of the basin is quantitatively measured by various factors such as the Form Factor, Circularity Ratio, Elongation Ratio and Compactness Coefficient (Reddy, 2008). The Form Factor (FF) is defined as the ratio of average width to the axial length of the watershed [Suresh, 2008]:

$$
\mathrm{FF}=\frac{\text { Average width of Watershed }}{\text { Axial length of watershed }}=\frac{\mathrm{B}}{\mathrm{L}} \text {. }
$$

The Circularity Ratio (CR) is defined as the ratio of the basin area to the area of the circle whose perimeter is equal to the perimeter of the basin:

$$
\mathrm{CR}=\frac{4 \pi \mathrm{A}}{\mathrm{P}^{2}}
$$

where: $\mathrm{P}$ - basin perimeter,

$\mathrm{A}-$ basin area.
This can also be estimated from the ratio of basin area to the area of a circle having a perimeter equal to the perimeter of the basin.

The Elongation Ratio (ER) is the ratio of the diameter $\mathrm{D}_{\mathrm{e}}$ of a circle whose area is the same as the area of the basin to the length of the basin [Reddy, 2008].

$$
\mathrm{ER}=\frac{\mathrm{D}_{\mathrm{e}}}{\mathrm{L}}=\frac{2}{\mathrm{~L}} \sqrt{\frac{\mathrm{A}}{\pi}}
$$

where: $\mathrm{L}$ - basin length, $\mathrm{A}$ - basin area.

The Compactness Coefficient (CC) is the ratio of perimeter of watershed to the circumference of a circle, whose area is equal to the area of the watershed and expressed as [Suresh, 2008]:

$\mathrm{CC}=\frac{\text { Perimeter of basin }}{\text { circumference of a circle whose area is equal to the basin area }}(4)$

Another parameter related to basin shape is the Shape Factor, which is defined as the ratio of the main stream length to the diameter of a circle having the same area as the watershed (inverse of the elongation ratio). The Unity Shape Factor is the ratio of the basin length to the square root of the basin area.

- Catchment Slope affects momentum of runoff and reflects the rate of change of elevation with respect to distance along the principal flow path.

- Drainage Density (DD) is expressed as the total length of all stream channels (perennial and intermittent) per unit area of the basin and serves as an index of the areal channel development of the basin:

$$
\mathrm{DD}=\frac{\mathrm{L}_{\mathrm{s}}}{\mathrm{A}}
$$

where: $\mathrm{L}_{\mathrm{s}}$ - total length of all stream channels in the basin, A - basin area.

- The Constant of Channel Maintenance is the reciprocal of the drainage density.

- Ruggedness Number is a product of basin relief and drainage density.

- Drainage Texture is the ratio of the total number of streams of all orders to the basin perimeter. This does not depend on the lithology, infiltration capacity and relief aspect of the terrain [Zende and Nagrajan, 2011 [ and its quantitative description is so difficult that qualitative expressions such as coarse, medium and fine are usually applied [Matsuda, 2004].

- The Stream Density is obtained as the ratio of the number of streams to the area of the basin [Reddy, 2008]. It can also be expressed 
as the number of streams per square kilometre [Raghunath, 2008].

- The Bifurcation Ratio is the ratio of the number $\mathrm{N}_{\mathrm{i}}$ of channels of order $\mathrm{i}$ to the number $\mathrm{N}_{\mathrm{i}+1}$ of channels of order $i+1$. This is relatively constant from one order to another and is known as Horton's Law of stream numbers [Chow et al., 1988].

- The Fitness Ratio is the ratio of the main channel length to the length of the basin perimeter, which is a measure of topographic fitness.

- The Wandering Ratio is the ratio of the main stream length to the valley length. The valley length is the straight line distance between outlet of the basin and the farthest point on the ridge [Seth et al., 1998].

- The Watershed Eccentricity is expressed as:

$$
\tau=\frac{\sqrt{\left(\left|\left(L_{c}^{2}-W_{c}^{2}\right)\right|\right)}}{W_{c}}
$$

where: $\tau$ - a dimensionless factor called watershed eccentricity, $\mathrm{L}_{\mathrm{c}}-$ straight length from the watershed mouth to the centre of mass of the watershed in the same unit, $\mathrm{W}_{\mathrm{c}}$ - width of the watershed at the centre of mass and perpendicular to $\mathrm{L}_{\mathrm{c}}$.

- Sinuosity Index is the ratio of channel length to down valley distance.

- Basin Infiltration Number is the product of the drainage density and the stream frequency. It gives an idea of the infiltration characteristics of the watershed [Pareta \& Pareta, 2011].

The obtained data for the selected basins was subjected to a principal component analysis (PCA), a variable reduction technique. In this procedure, new variables are derived (principal components) which are a linear combination of the original variables. This renders some variables redundant as a result of their correlation with one another. Detailed description of the procedure will be found in Abdi \& Williams [2010].

\section{RESULTS AND DISCUSSIONS}

The chosen catchments are the Oyun, Asa, Gongola, Taraba and Katsina Ala rivers basins (Figure 1).

The control points of the Asa river basin was taken as the Asa Dam (Ilorin) (Lat. $8.50^{\circ} \mathrm{N}$, Long $4.55^{\circ} \mathrm{E}$ ), Oyun river basin at Offa (Lat. $8.15^{\circ} \mathrm{N}$, Long. $4.72^{\circ} \mathrm{E}$ ), Gongola river basin at Dindima (Lat. $10.22^{\circ} \mathrm{N}$, Long. $1015^{\circ} \mathrm{E}$ ), Taraba river basin at Gassol (Lat. $8.52^{\circ} \mathrm{N}$, Long. $10.46^{\circ} \mathrm{E}$ ) and Katsina - Ala river basin at Sevav (Lat. $7.43^{\circ} \mathrm{N}$, Long. $\left.9.25^{\circ} \mathrm{E}\right)$. The basins have fern leaf shapes. With this shape, the times of concentration are long since the tributaries are of varying lengths. The discharges from the catchments are thus distributed over a long period. The shapes of the drainage basins as defined by various parameters are given in Table 1.

Basin Slope. The average slopes of the basins are in Table 2. This was obtained by finding the slope of various sections of the main channel profile and finding the average.

Drainage Density. This is a useful numerical measure of landscape dissection and runoff potential. While it is a result of interacting factors controlling surface runoff, it also influences the water output from the drainage basins [Malik

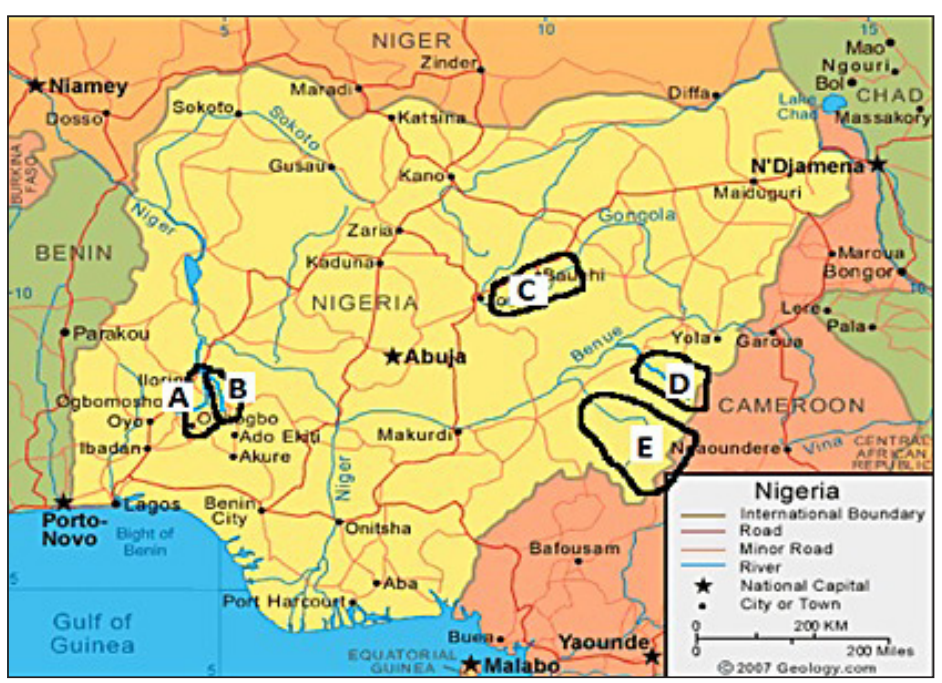

Figure 1. Location of the study basins
A - Asa River Basin B - Oyun River Basin C - Gongola River Basin D - Taraba River Basin E - Katsina-Ala River Basin 
Table 1. Shape parameters of the basins

\begin{tabular}{|c|l|c|c|c|c|c|}
\hline $\mathrm{S} / \mathrm{N}$ & \multicolumn{1}{|c|}{ Parameter } & Oyun & Asa & Gongola & Katsina Ala & Taraba \\
\hline 1. & Form Factor & 0.23 & 0.33 & 0.41 & 0.33 & 0.48 \\
\hline 2. & Circularity Ratio & 0.40 & 0.47 & 0.60 & 0.33 & 0.68 \\
\hline 3. & Elongation Ratio & 0.41 & 0.59 & 0.72 & 0.65 & 0.78 \\
\hline 4. & Compactness Coefficient & 1.57 & 1.45 & 1.29 & 1.73 & 1.21 \\
\hline 5. & Shape Factor & 2.44 & 1.68 & 1.38 & 1.54 & 1.28 \\
\hline 6. & Unity Shape Factor & 2.75 & 1.89 & 1.56 & 1.73 & 1.44 \\
\hline
\end{tabular}

Table 2. Slope parameters of the basins

\begin{tabular}{|l|c|c|c|c|c|}
\hline \multicolumn{1}{|c|}{ Parameter } & Oyun & Asa & Gongola & Katsina Ala & Taraba \\
\hline Average Slope of Main Channel (\%) & 0.615 & 0.303 & 0.420 & 0.733 & 0.106 \\
\hline Slope of Hydraulic Grade line (\%) & 0.475 & 0.242 & 0.483 & 0.901 & 0.111 \\
\hline Relative Relief (\%) & 0.230 & 0.080 & 0.165 & 0.253 & 0.030 \\
\hline
\end{tabular}

Table 3. Length comparisons for the basins

\begin{tabular}{|l|c|c|c|c|c|}
\hline \multicolumn{1}{|c|}{ Parameter } & Oyun & Asa & Gongola & Katsina Ala & Taraba \\
\hline Drainage density $\left(\mathrm{km} / \mathrm{km}^{2}\right)$ & 0.313 & 0.286 & 0.34 & 0.316 & 0.292 \\
\hline Average length of overland flow $(\mathrm{km})$ & 3.19 & 3.50 & 2.94 & 3.16 & 3.42 \\
\hline
\end{tabular}

Table 4. Relief parameters for the river basins

\begin{tabular}{|l|c|c|c|c|c|}
\hline \multicolumn{1}{|c|}{ Parameter } & Oyun & Asa & Gongola & Katsina Ala & Taraba \\
\hline Drainage texture & 0.83 & 1.2 & 0.785 & 0.386 & 0.712 \\
\hline Ruggedness number & 0.0407 & 0.0744 & 0.323 & 0.269 & 0.465 \\
\hline Constant of channel maintenance $\left(\mathrm{km}^{2} / \mathrm{km}\right)$ & 3.19 & 3.50 & 2.94 & 3.16 & 3.42 \\
\hline Stream density & 0.066 & 0.071 & 0.084 & 0.063 & 0.068 \\
\hline Bifurcation ratio & 3.0 & 4.7 & 5.22 & 3.0 & 2.5 \\
\hline Fitness ratio & 0.38 & 0.40 & 0.394 & 0.345 & 0.391 \\
\hline Wandering ratio & 1.16 & 1.01 & 1.15 & 1.23 & 1.05 \\
\hline Sinuosity index & 1.04 & 1.08 & 1.08 & 1.12 & 1.04 \\
\hline Watershed eccentricity & 0.46 & 0.55 & 0.58 & 0.69 & 0.55 \\
\hline Infiltration number & 0.021 & 0.020 & 0.029 & 0.020 & 0.020 \\
\hline
\end{tabular}

et al., 2011]. Table 3 shows the drainage densities for the five basins.

Basin Relief. Basin relief parameters are given in Table 4. Drainage Texture (DT) for the basins is low $(<2.5)$. This is indicative of a very coarse soil texture. The Ruggedness Number (RN) indicates the structural complexity of the basin terrain. Basins having high RN are susceptible to erosion [Bagyaraj \& Gurugnanam, 2011].

Morphometric Parameters Selection. A quick correlation analysis of the shape parameters shows that the bifurcation ratio has a high correlation with the other shape factors (Table 5), which was why it was correlated with other basin relief parameters listed in Table 4. The correlation coefficient between the relief parameters is shown in Table 6. Some parameters were excluded because they depend totally on some other parameters which are already included (for example, the Constant of Channel Maintenance is the inverse of the drainage density and was therefore excluded).

The identification of unique parameter sets to run a specific model efficiently has always been difficult because of parameter interdependence as seen in Tables 5 and 6. To determine how many parameters are required to describe the model, a principal component analysis was 
Table 5. Correlation coefficients between shape parameters of the study basins

\begin{tabular}{|c|c|c|c|c|c|c|c|}
\hline & FF & CR & ER & CC & SF & USF & BR \\
\hline FF & $\mathbf{1 . 0 0 0 0}$ & & & & & & \\
\hline CR & $\mathbf{0 . 6 4 8 8}$ & $\mathbf{1 . 0 0 0 0}$ & & & & & \\
\hline ER & 0.9768 & 0.4739 & $\mathbf{1 . 0 0 0 0}$ & & & & \\
\hline CC & -0.5436 & $\mathbf{- 0 . 9 8 6 6}$ & -0.3517 & $\mathbf{1 . 0 0 0 0}$ & & & \\
\hline SF & $-\mathbf{0 . 9 5 5 6}$ & -0.4084 & $-\mathbf{0 . 9 8 7 7}$ & 0.2978 & $\mathbf{1 . 0 0 0 0}$ & & \\
\hline USF & $\mathbf{- 0 . 9 5 4 9}$ & -0.4072 & $\mathbf{- 0 . 9 8 6 9}$ & 0.2972 & $\mathbf{1 . 0 0 0 0}$ & $\mathbf{1 . 0 0 0 0}$ & \\
\hline BR & $\mathbf{0 . 7 5 9 0}$ & $\mathbf{0 . 9 2 2 7}$ & $\mathbf{0 . 6 0 8 9}$ & $-\mathbf{0 . 9 1 6 8}$ & -0.5994 & $\mathbf{- 0 . 5 9 9 9}$ & $\mathbf{1 . 0 0 0 0}$ \\
\hline
\end{tabular}

$\mathrm{FF}=$ Form Factor

$\mathrm{CC}=$ Compactness Coefficient

$\mathrm{BR}=$ Bifurcation Ratio
$\mathrm{CR}=$ Circularity Ratio

$\mathrm{SF}=$ Shape Factor
$\mathrm{ER}=$ Elongation Ratio

USF = Unity Shape Factor

Table 6. Correlation coefficients between relief parameters of the study basins

\begin{tabular}{|c|c|c|c|c|c|c|c|c|c|}
\hline & Slope & DD & DT & RN & SD & BR & FR & WR & WE \\
\hline Slope & 1.0000 & & & & & & & & \\
\hline DD & 0.2978 & 1.0000 & & & & & & & \\
\hline DT & -0.8863 & -0.5640 & 1.0000 & & & & & & \\
\hline $\mathrm{RN}$ & 0.1766 & 0.7525 & -0.6104 & 1.0000 & & & & & \\
\hline SD & -0.6488 & 0.5319 & 0.3203 & 0.4730 & 1.0000 & & & & \\
\hline $\mathrm{BR}$ & -0.8743 & 0.1454 & 0.5615 & 0.3112 & 0.9010 & 1.0000 & & & \\
\hline FR & -0.9264 & -0.1630 & 0.9055 & -0.3118 & 0.6741 & 0.7763 & 1.0000 & & \\
\hline WR & 0.9056 & -0.6642 & -0.9649 & 0.5254 & -0.2691 & -0.5938 & -0.8241 & 1.0000 & \\
\hline WE & 0.3363 & 0.1860 & -0.6452 & 0.7410 & -0.1061 & -0.0360 & -0.6361 & 0.4309 & 1.0000 \\
\hline
\end{tabular}

$\mathrm{DD}=$ Drainage Density

$\mathrm{SD}=$ Stream Density

$\mathrm{WR}=$ Wandering Ratio
DT = Drainage Texture

$\mathrm{BR}=$ Bifurcation Ratio

WE $=$ Watershed Eccentricity
$\mathrm{RN}=$ Ruggedness Number

$\mathrm{FR}=$ Fitness Ratio

Table 7. Eigenvalues of the correlation matrix of the parameters

\begin{tabular}{|c|c|c|c|c|}
\hline & Eigenvalue & Difference & Proportion (\%) & Cumulative (\%) \\
\hline 1. & 5.162 & 2.326 & 57.36 & 57.36 \\
\hline 2. & 2.837 & 1.836 & 31.518 & 88.878 \\
\hline 3. & 1.001 & 1.001 & 11.122 & 100 \\
\hline 4. & $9.98 \mathrm{E}-16$ & $6.01 \mathrm{E}-16$ & $1.11 \mathrm{E}-14$ & 100 \\
\hline 5. & $3.97 \mathrm{E}-16$ & $1.02 \mathrm{E}-16$ & $4.41 \mathrm{E}-15$ & 100 \\
\hline 6. & $2.95 \mathrm{E}-16$ & $2.22 \mathrm{E}-16$ & $3.28 \mathrm{E}-15$ & 100 \\
\hline 7. & $7.32 \mathrm{E}-17$ & $7.32 \mathrm{E}-17$ & $8.13 \mathrm{E}-16$ & 100 \\
\hline
\end{tabular}

Table 8. Component loadings of the principal components

\begin{tabular}{|l|c|c|c|}
\hline & PC 1 & PC 2 & PC 3 \\
\hline Slope & $\mathbf{0 . 9 5 3}$ & -0.235 & 0.191 \\
\hline Drainage density & 0.405 & $\mathbf{0 . 7 7 3}$ & 0.489 \\
\hline Drainage texture & $\mathbf{- 0 . 9 7 8}$ & -0.207 & -0.015 \\
\hline Ruggedness number & 0.442 & $\mathbf{0 . 8 7 3}$ & -0.206 \\
\hline Stream density & -0.509 & $\mathbf{0 . 8 4 2}$ & 0.179 \\
\hline Bifurcation ratio & $\mathbf{- 0 . 7 1 5}$ & $\mathbf{0 . 6 7 6}$ & -0.179 \\
\hline Fitness ratio & $\mathbf{- 0 . 9 6 6}$ & 0.177 & 0.188 \\
\hline Wandering ratio & $\mathbf{0 . 9 4 2}$ & 0.191 & 0.277 \\
\hline Watershed eccentricity & 0.590 & 0.382 & $\mathbf{- 0 . 7 1 2}$ \\
\hline
\end{tabular}

conducted on the parameters. The result of the eigenvalues is presented in Table 7 and the component loadings is given in Table 8 .

In Table 7, it can be observed that three parameters have eigenvalues greater than unity and they account for $100 \%$ of the variance. From Table 8, the Fitness Ratio (FR), Ruggedness Number (RN) and Watershed Eccentricity has a high component loading in the three principal components and will thus adequately represent the other parameters. The basin eccentricity has a good correlation with the $F R$ and $R N$. 


\section{CONCLUSIONS}

The conversion of rainfall to runoff in a basin is a complex process. However, morphometric properties of the basin play an important role in the process. The predictions of flows in ungauged basins (PUB) as is often required in hydrological studies are inevitably based on the rainfall - runoff models. It has been shown that over-parametization of models does not necessarily make the model more efficient [Perrin et al., 2001] and therefore there is some advantage in reducing the number of parameters required for hydrological modelling if important information is not lost. In this case, it has been shown that despite the array of parameters for basin description, only three (RN, FR, and WE) can adequately describe the morphometric features of a basin in central Nigeria. This reduces the time and effort expended on the determination of all the various parameters when the three are adequate representation.

\section{REFERENCES}

1. Abdi H., Williams L.J., 2010. Principal component analysis. Wiley Interdisciplinary Reviews: Computational Statistics, 2(4), 433-459.

2. Ajibade L.T., Ifabiyi I.P., Iroye K.A., Ogunteru S., 2010. Morphometric analysis of Ogunpa and Ogbere drainage basins, Ibadan, Nigeria. Ethiopian Journal of Environmental Studies and Management, 3(1), 13-19.

3. Al-Saud M., 2009. Morphometric analysis of Wadi Aurnah drainage system, Western Arabian Peninsula. The Open Hydrology Journal, 3, 1-10.

4. Bagyaraj M., Gurugnanam B., 2011. Significance of morphometry studies, soil characteristics, erosion phenomena and landform processes using remote sensing and GIS for Kodaikanal Hills. A global biodiversity hotpot in Western Ghats, Dindigul District, Tamil Nadu, South India. Research Journal of Environmental and Earth Sciences, 3(3), 221-233.

5. Chow V.T., Maidment D.R., Mays L.W., 1988. Applied hydrology. McGraw Hill Book Company. New York, USA.

6. Doad A.P., Warghat S.R., Khadse S.P., 2012. Morphometric analysis for hydrological studies using Geographical Information System: A case study. International Journal of Engineering Research and Technology, 1(5), 1-8.

7. Eze E.B., Efiong J., 2010. Morphometric parameters of the Calabar River Basin: Implication for hydrologic process. Journal of Geography and Geology, 2(1), 18-26.

8. Ezemonye M.N., Emeribe C.N., 2013. Appraisal of the Hydrological Potential of Ungauged Basin Using Morphometric Parameters. Ethiopian Journal of Environmental Studies and Management, 6(4), 376-380.

9. Golekar R.B., Baride M.V., Patil S.N., 2013. Morphometric Analysis and Hydrogeological Implication: Anjani and Jhiri River Basin, Maharashtra, India. Archives of Applied Science Research, 5(2), 33-41.

10. Howard A.D., 1990. Role of Hypsometry and Planform in Basin Hydrologic Response. Hydrological Processes, 4, 373-385.

11. Malik M.I., Bhat M.S., Kuchay N.A., 2011. Watershed Based Drainage Morphometric Analysis of Lidder Catchment in Kashmir Valley Using Geographical Information System. Recent Research in Science and Technology, 3(4), 118-126.

12. Matsuda I., 2004. River Morphology and Channel Processes. In: James C.I. Dooge (Ed.) Fresh Surface Water. Encyclopaedia of Life Support Systems (EOLSS), Developed under the Auspices of the UNESCO, EOLSS Publishers, Oxford, UK, (http://www.eolss.net).

13. Nanda A.M., Ahmed P., Kanth T.A., Hajam R. A., 2014. Morphometric Analysis of Sandran Drainage Basin ( $\mathrm{J} \& \mathrm{~K}$ ) Using Geo-spatial Technology. Earth Science India, 7(2), 55-66.

14. Pal B., Silesh S., Pal D.K., 2012. Morphometric and Hydrological Analysis and Mapping for Watut Watershed Using Remote Sensing and GIS Techniques", International Journal of Advances in Engineering and Technology, 2(1), 357-368.

15. Pareta K., 2012. Hydromorphogeological Study of Karawan Watershed Using GIS and Remote Sensing Techniques. Environmental Systems Research Institute (ESRI) International User Conference, San Diego, USA.

16. Pareta K., Pareta U., 2011. Quantitative Morphometric Analysis of a Watershed of Yamuna Basin, India Using ASTER (DEM) Data and GIS. International Journal of Geomatics and Geosciences, 2(1), 248-269.

17. Perrin C., Michel C., Andreassian V., 2001. Does a Large Number of Parameters Enhance Model Performance? Comparative Assessment of Common Catchment Model Structures of 429 Catchments. Journal of Hydrology, 242, 275-301.

18. Pingale S.M., Chandra H., Sharma H.C., Mishra S.S., 2012. Morphometric Analysis of Maun Watershed in Tehri - Garhwal District of Uttarakhand Using GIS", International Journal of Geomatics and Geosciences, 3(2), 373-387.

19. Pisal P.A., Yadav A.S., Chavan A.B., 2013. Mor- 
phometric Analysis of Bhogavati River Basin, Kolhapur District, Maharashtra, India. Second International Conference on Emerging Trends in Engineering, Journal of Mechanical and Civil Engineering, 1-8.

20. Raghunath H.M., 2008. Hydrological principles. Published by New Age International (P) Ltd. Delhi.

21. Reddy P.J.R., 2008. A textbook of hydrology. Published by University Science Press, India.

22. Seth S.M., Ramasastri K.S., Rao S.V.N., 1998. Representative Basin Studies: Morphometric Analysis of Suddagedda Basin, Andra Pradesh. Published by the National Institute of Hydrology, India.
23. Suresh R., 2008. Land and Water Management Principles", Published by A.K. Jain for Standard Publishers Distributors, Delhi, India.

24. Zende A.N., Nagrajan R., 2011. Drainage Morphology Approach for Water Resources Development of Sub - Watershed in Krishna Basin. International Journal of Computer \& Communication Technology, 2(8), 13-21.

25. Zhang X., Ball G., Guertin P., Halper E., Zhang L., 2015. Integrating GIS and Remote Sensing With Urban Hydrology. Advanced Resource Technology Group, School of Renewable Natural Resources, University of Arizona, Tucson, USA. 